\title{
PENGARUH EKSTRAK BIJI PEPAYA (carica papaya L.) DAN EKSTRAK DAUN MIMBA (Azadirachta indica A.Juss) DAN CAMPURAN EKSTRAK BIJI PEPAYA (carica papaya L.) DAN EKSTRAK DAUN MIMBA (Azadirachta indica A.Juss) TERHADAP DIAMETER TUBULUS SEMINIFERUS, SEL LEYDIG DAN BOBOT TESTIS MENCIT (Mus musculus)
}

\author{
Apolonia M. ${ }^{1}$ dan Sukarjati ${ }^{2}$ \\ 1) Mahasiswa Prodi Biologi F.MIPA Universitas PGRI Adi Buana Surabaya \\ ${ }^{2)}$ Staf pengajar Prodi Biologi F.MIPA Universitas PGRI Adi Buana Surabaya
}

\begin{abstract}
Papaya (Carica papaya L.) and Neem (Azadirachia indica A.Juss) Tree are planted as an ornamental tree and have a character as a brush plant. They vegetated in tropical and subtropical region. The seed of papaya and Neem leaf are also include of a potential plants as a antifertility. Types of bioactif compounds contained in plants, the main compounds that are derived from the steroids, alkaloids, isoflavanoid, tripernoid, and activity as xanthon antifertilities. This encourages the researcher to know the influence of ethanol seed papaya extract and neem leaf extract towards diameter of seminiferous tubule, leydig cell and the testicular weight mice (Mus musculus). The sample of this research is the mice by as much as 21 tail with a weight of 20-30 grams, aged 2.5 months. Murine in to 3 groups, each group is divided 7 treatment. As for the treatments given are extracts of flowers, leaves, and roots of hibiscus with dose control, 50, and $100 \mathrm{mg} / \mathrm{kg}$. Granting of extracts for 35 days. On day 37 mice are in surgery for testicular weight to observations taken, the volume of the testes. The testes then made preparations and measured diameter of seminiferous tubules. This research is experimental research using Random Complete Group. The data obtained were analyzed with variant analysis (ANOVA) in one direction and continued with test LSD (Least Significant Different). The results of the research there shows the influence of the ethanol papaya seed extract, meem leaf extracy and also the micture of papaya seed extract and neem leaf extract towards the weight of mice, leydig cell and the diameter of seminiferous tubule $(\mathrm{P}<0.05)$. The best result to decrease the testicular weight and diameter of seminiferous tubule was showed by the neem with the weight of $100 \mathrm{mg} / \mathrm{kg} \mathrm{BB}$. The best result to decrease the leydig cell was showed on the mixture of papaya seed extract and neem leaf extract in dosage of $100 \mathrm{mg} / \mathrm{kg}$ BB. This study showed that papaya seed extract, neem leaf extract and the mixture of papaya seed extract and neem leaf extract able to decrease the testicular weight, diameter of seminiferous and leydig cell. In the next day, this research supposed to be able as an antifertility in male.
\end{abstract}

Keywords: papaya seed extract, neem leaf extract, mixture of papaya seed extract and neem leaf extract toward testicles, diameter of seminiferous tubules, leydig cell (Mus musculus)

\section{PENDAHULUAN}

Tanaman pepaya (Carica papaya L.) merupakan tanaman herbal yang populer di kalangan masyarakat. Selain dapat hidup di berbagai tempat di Indonesia, tanaman pepaya ini memiliki waktu tumbuh yang relatif singkat. Di dalam ekstrak biji pepaya terkandung senyawa alkaloid, enzim papain, flavonoid, glikosid, karpisod, sakarosa, dekstrosa, levulosa, benzilgluko-sinolat dan tannin (Ardina, 2007). Penelitian yang dilakukan oleh Muslichah dan Wiratmo (2013) tentang efek antifertilitas dari biji pepaya (Carica Papaya L.) terhadap tikus jantan galur wistar diperoleh hasil bahwa fraksi П-heksana, fraksi kloroform dan fraksi metanol biji pepaya dosis $100 \mathrm{mg} / \mathrm{kg}$ BB mampu menurunkan jumlah spermatozoa, motilitas, meningkatkan abnormalitas spermatozoa dan menurunkan viabilitas spermatozoa.

Selain tanaman pepaya, terdapat juga tanaman mimba yang banyak ditemukan di Indonesia dan dianggap sebagai tanaman liar bagi masyarakat. Mimba (Azadirachia indica Juss) juga merupakan bahan alam yang kaya akan manfaat. Daun mimba memiliki kandungan senyawa azadirichtin, flavonoid, tritepenoid dan saponin (Handayani, 2011).

Senyawa yang berfungsi sebagai penyusun fertilitas adalah Flavonoid, Tritepenoid, Saponin dan Tanin. Pada biji pepaya tidak mengandung senyawa Tritepenoid dan Saponin. Sedangkan daun mimba tidak mengandung senyawa tanin.Untuk itu perlu di teliti tentang kombinasi ekstrak biji pepaya dengan daun mimba terhadap Diameter tubulus seminiferus, Sel leydig, dan Bobot testis.

\section{MATERI DAN METODE PENELITIAN}

Jenis penelitian ini adalah penelitian eksperimental. Penelitian ini bertujuan menyelidiki 
kemungkinan saling hubungan sebab-akibat dengan cara mengenakan satu atau lebih kondisi perlakuan kepada satu atau lebih kelompok kontrol yang tidak dikenai kondisi perlakuan itu (Notoatmodjo, 2005). Rancangan penelitian yang digunakan adalah Rancangan Acak Lengkap (RAL).Rancangan Acak Lengkap merupakan rancangan yang paling sederhana. Ciri dari rancangan ini adalah bahan percobaan yang digunakan harus homogeny. Kehomogenan yang di maksud disini yaitu bahwa selain makhluk ( hewan / tumbuhan ) yang digunakan sebagai bahan percobaan. Kehomogenan juga diperlukan pada tempat percobaan yang digunakan seperti laboraturium, kandang dan lahan pertanian. Umur, tinggi ,bobot, bentuk, ukuran , dan faktor lainnya

\section{Persiapan hewan uji}

Sebelum mempersiapkan hewan coba terlebih dahulu menyiapkan tempat pemeliharaan hewan coba yang meliputi kandang,tempat makan dan tempat minum mencit dan pakan mencit, kemudian mencit diaklimatisasi pada suhu laboratorium selama 7 hari agar dapat beradaptasi dengan kondisi lingkungan yang baru.

Selama proses adaptasi diberi makanan standar,dilakukan pengamatan secara umum serta ditimbang berat badannya sebelum menentukan dosis yang akan diberikan.

\section{Pembuatan Ekstrak dan Perlakuan}

Jenis ekstrak meliputi ekstrak biji pepaya (A), ekstrak daun mimba (B), kombinasi antara esktrak biji pepaya dan ekstrak daun mimba (C). Biji Pepaya dan daun mimba dikering anginkan secara terpisah. Selanjutnya di buat serbuk dengan cara diblender. Sejumlah 100 gr serbuk biji pepaya dimaserasi dengan $1000 \mathrm{ml}$ ethanol $80 \%$. 100 gr serbuk daun mimba dimaserasi dengan $1000 \mathrm{ml}$ ethanol $80 \%$. Hasil maserasi cairan dilakukan distilasi dan di keringkan sehingga diperoleh ekstrak kental. Ekstrak yang diperoleh selanjutnya digunakan untuk perlakuan. Perlakuan yang digunakan adalah sebagai berikut: Dosis ekstrak yang digunakan adalah 0 $\mathrm{mg} / \mathrm{kg} \mathrm{BB}, 50 \mathrm{mg} / \mathrm{kg} \mathrm{BB}, 100 \mathrm{mg} / \mathrm{kg}$ BB. Diberi perlakuan pada mencit yaitu dengan 9 perlakuan yaitu 3 kelompok sebagai kontrol dan 2 kelompok diberi konsentrasi berbagai eksrak yang diberikan secara oral dengan menggunakan alat pencekok oral (sonde). Masing - masing perlakuan diulang 3 kali ulangan.

\section{Pemerolehan data}

Pemberian ekstrak biji pepaya dan ekstrak daun mimba serta kombinasi antara biji pepaya dan daun mimba, dilarutkan dengan aquadest pada suhu $80^{\circ} \mathrm{C}$ dan di diamkan selama 24 jam. Ekstrak diberikan secara oral menggunakan sonde dengan volume tidak melebihi intragestik mencit $(1 \mathrm{ml})$. Ekstrak diberikan pada mencit sekali setiap hari yaitu pada pagi hari jam 08.00 - 10.30 WIB selama 36 hari dengan dosis yang telah dihitung sesuai dengan berat $\mathrm{mg} / \mathrm{kg}$ BB mencit. Pada hari ke-37 seluruh mencit dibius dengan eter atau kloroform, dibedah dan diambil kedua testisnya untuk dibuat preparat mikroanatomi sesuai standar laboratorium.

\section{Analisis statistika}

Jumlah sel-sel spermatogenik yaitu Berat testis, sel leydig dan Diameter tubulus seminiferus dianalisis dengan menggunakan uji One way ANOVA. Jika hasil dari uji One way ANOVA menunjukkan perbedaan yang signifikan $(p<0,05)$ maka analisis data dilanjutkan dengan menggunakan uji LSD (Least Significant Different).

\section{HASIL PENELITIAN}

\section{Bobot Testis}

Pada hasil peneletian dan analisa pengaruh pemberian ekstrak biji pepaya (carica papaya $L$ ), ekstrak daun mimba ( Azadirahcta indica A.Juss) dan campuran ekstrak biji pepaya ( carica papaya L), dan ekstrak daun mimba( Azadirahcta indica A.Juss ) terhadap penurunan bobot testis mencit disajikan dalam lampiran 1. Hasil penelitian menunjukan bahwa perlakuan ekstrak biji pepaya, ekstrak daun mimba dan campuran ekstrak biji pepaya da daun mimba berpengaruh signifikan ( $\mathrm{P}<0,05)$ terhadap bobot testis mencit ( Mus musculus). 


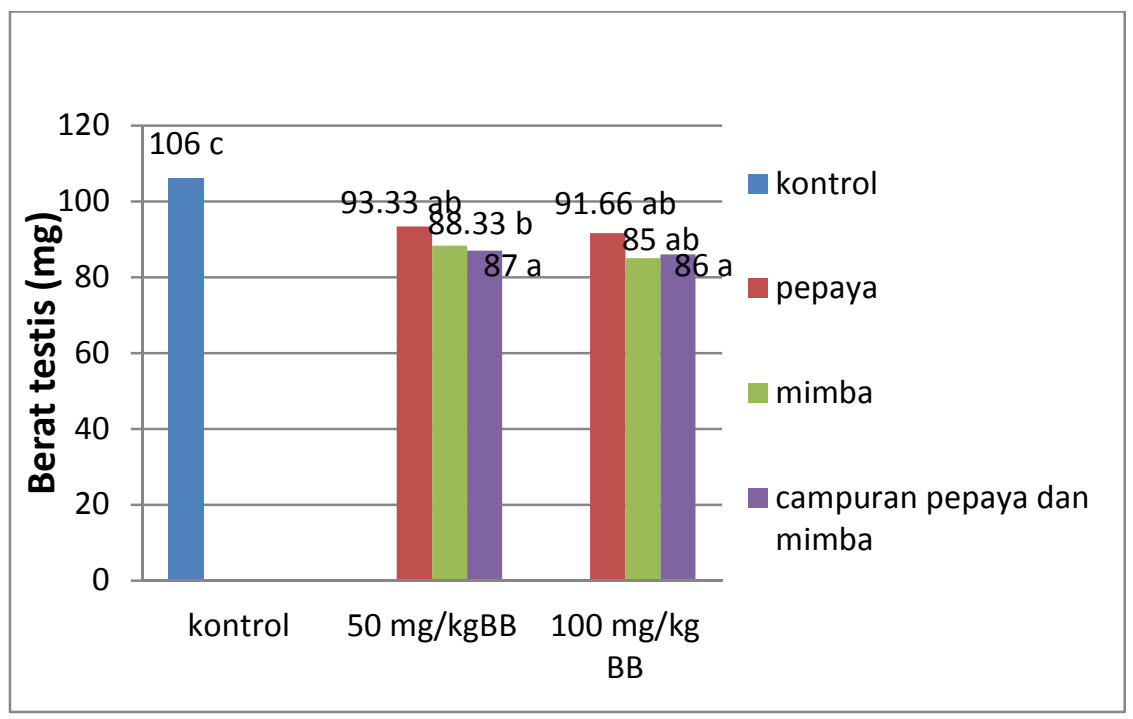

Berat testis mencit (Mus musculus) yang diberi ekstrak biji pepaya dan daun mimba dan campuran dengan berbagai dosis. Hasil penelitian bahwa perlakuan dalam biji pepaya dan daun mimba juga campuran berpengaruh signifikan $(\mathrm{P}<0,05)$ terhadap berat testis mencit.

Berat testis mencit pada konsentrasi $0 \mathrm{mg} / \mathrm{kg}$ $\mathrm{BB}$ signifikan $(\mathrm{P}<0,05$ ) biji pepaya $50 \mathrm{mg} / \mathrm{kg} \mathrm{BB}$, daun mimba $50 \mathrm{mg} / \mathrm{kg} \mathrm{BB}$, campuran $50 \mathrm{mg} / \mathrm{kg} \mathrm{BB}$ , biji pepaya $100 \mathrm{mg} / \mathrm{kg} \mathrm{BB}$, daun mimba $100 \mathrm{mg} / \mathrm{kg}$ $\mathrm{BB}$, campuran $100 \mathrm{mg} / \mathrm{kg}$ BB signifikan $(\mathrm{P}<0,05)$ pada biji pepaya $50 \mathrm{mg} / \mathrm{kg} \mathrm{BB}$ signifikan $(\mathrm{P}<0,05)$ kontrol $0 \mathrm{mg} / \mathrm{kg} \mathrm{BB}$, daun mimba $100 \mathrm{mg} / \mathrm{kg}$ BB , campuran $50 \mathrm{mg} / \mathrm{kg} \mathrm{BB}$, campuran $100 \mathrm{mg} / \mathrm{kg} \mathrm{BB}$ dan biji pepaya $100 \mathrm{mg} / \mathrm{kg} \mathrm{BB}$, daun mimba 50 $\mathrm{mg} / \mathrm{kg} \mathrm{BB}$ signifikan $(\mathrm{P}>0,05)$

berat testis mencit pada konsentrasi daun mimba $50 \mathrm{mg} / \mathrm{kg}$ BB signifikan ( $\mathrm{P}>0,05)$ kontrol 0 $\mathrm{mg} / \mathrm{kg} \mathrm{BB}$, biji pepaya $50 \mathrm{mg} / \mathrm{kg} \mathrm{BB}$, daun mimba $100 \mathrm{mg} / \mathrm{kg} \mathrm{BB}$, campuran $50 \mathrm{mg} / \mathrm{kg}$ BB , biji pepaya $100 \mathrm{mg} / \mathrm{kg} \mathrm{BB}$, campuran $100 \mathrm{mg} / \mathrm{kg} \mathrm{BB}$ signifikan $(\mathrm{P}<0,05)$. pada biji pepaya $100 \mathrm{mg} / \mathrm{kg} \mathrm{BB}$ signifikan $(\mathrm{P}<0,05)$ kontrol $0 \mathrm{mg} / \mathrm{kg} \mathrm{BB}$, daun mimba $100 \mathrm{mg} / \mathrm{kg} \mathrm{BB}$, campuran biji pepaya dan daun mimba $100 \mathrm{mg} / \mathrm{kg}$ BB campuran $100 \mathrm{mg} / \mathrm{kg}$ $\mathrm{BB}$ dan biji pepaya $50 \mathrm{mg} / \mathrm{kg} \mathrm{BB}$, daun mimba 50 $\mathrm{mg} / \mathrm{kg} \mathrm{BB}$, campuran $50 \mathrm{mg} / \mathrm{kg}$ BB signifikansi (P> 0,05). pada konsentrasi daun mimba $100 \mathrm{mg} / \mathrm{kg} \mathrm{BB}$ signifikan ( $\mathrm{P}<0,05$ ) kontrol $0 \mathrm{mg} / \mathrm{kg} \mathrm{BB}$, biji pepaya $50 \mathrm{mg} / \mathrm{kg} \mathrm{BB}$, pepaya $100 \mathrm{mg} / \mathrm{kg} \mathrm{BB}$. dan berbeda nyata dengan mimba $50 \mathrm{mg} / \mathrm{kg} \mathrm{BB}$, campuran $50 \mathrm{mg} / \mathrm{kg} \mathrm{BB}$, campuran $100 \mathrm{mg} / \mathrm{kg} \mathrm{BB}$ ( $\mathrm{P}>0,05)$ berat testis mencit pada konsentrasi campuran biji pepaya dan daun mimba $50 \mathrm{mg} / \mathrm{kg}$ BB signifikan $(\mathrm{P}<0,05)$ kontrol $0 \mathrm{mg} / \mathrm{kg} \mathrm{BB}$, biji pepaya $50 \mathrm{mg} / \mathrm{kg}$ $\mathrm{BB}$ dan biji pepaya $100 \mathrm{mg} / \mathrm{kg} \mathrm{BB}$, daun mimba 50 $\mathrm{mg} / \mathrm{kg} \mathrm{BB}$, mimba $100 \mathrm{mg} / \mathrm{kg} \mathrm{B}$, campuran 100 $\mathrm{mg} / \mathrm{kg}$ BB signifikansi

( $>$ 0,05). Pada campuran biji pepaya dan daun mimba $100 \mathrm{mg} / \mathrm{kg}$ BB signifikan $(\mathrm{P}<0,05)$ tidak kontrol $0 \mathrm{mg} / \mathrm{kg} \mathrm{BB}$, biji pepaya $50 \mathrm{mg} / \mathrm{kg} \mathrm{BB}$, biji pepaya $100 \mathrm{mg} / \mathrm{kg} \mathrm{BB}(\mathrm{P}<0,05)$ dan mimba 50 $\mathrm{mg} / \mathrm{kg} \mathrm{BB}$, mimba $100 \mathrm{mg} / \mathrm{kg} \mathrm{BB}$, campuran 50 $\mathrm{mg} / \mathrm{kg}$ BB signifikansi $(\mathrm{P}>0,05)$.

Konsentrasi yang terbaik untuk menurunkan berat testis mencit adalah mimba $100 \mathrm{mg} / \mathrm{kg}$ BB. Tetapi antara perlakuan mimba $100 \mathrm{mg} / \mathrm{kg} \mathrm{BB}$ dan campuran biji pepaya dan daun mimba $100 \mathrm{mg} / \mathrm{kg}$ BB secara statistik tidak berbeda nyata.

\section{Diameter Tubulus Seminiferus}

Pada hasil peneletian dan analisa pengaruh pemberian ekstrak biji pepaya (carica papaya $L$ ), ekstrak daun mimba (Azadirahcta indica A.Juss) dan campuran ekstrak biji pepaya ( carica papaya L), dan ekstrak daun mimba( Azadirahcta indica A.Juss ) terhadap penurunan diameter tubulus seminiferus mencit disajikan dalam lampiran 2 . Hasil penelitian menunjukan bahwa perlakuan ekstrak biji pepaya, ekstrak daun mimba dan campuran ekstrak biji pepaya da daun mimba berpengaruh signifikan $(\mathrm{P}<0,05)$ terhadap sel leydig mencit (Mus musculus). 


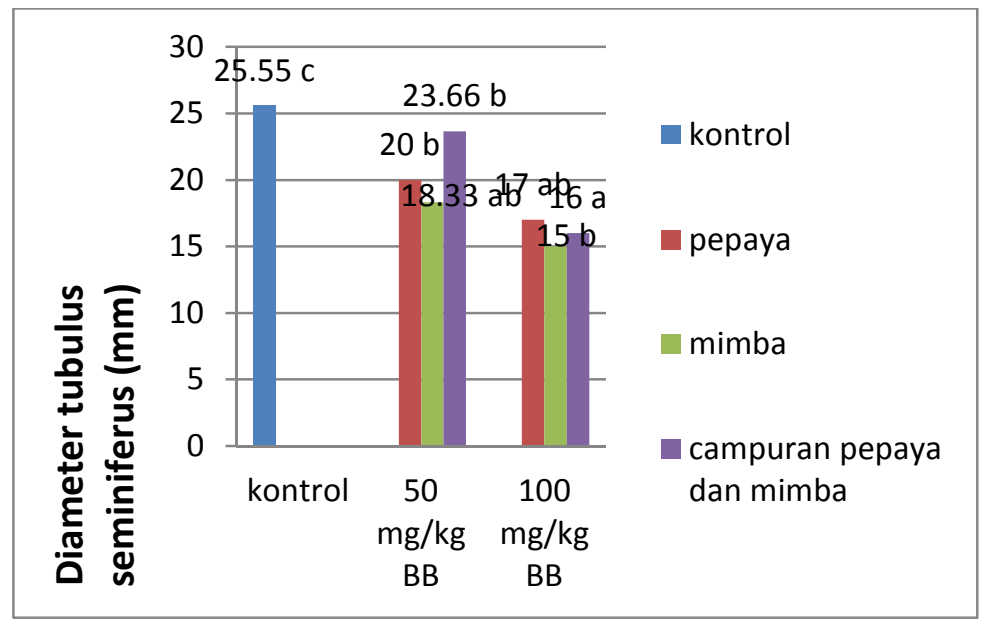

Diameter tubulus seminiferus mencit (Mus musculus) yang diberi ekstrak biji pepaya dan daun mimba dan campuran dengan berbagai dosis. Hasil penelitian bahwa perlakuan dalam biji pepaya dan daun mimba juga campuran berpengaruh signifikan ( $\mathrm{P}<0,05$ ) terhadap Diameter tubulus seminiferus.

Diameter tubulus seminiferus mencit pada Konsentrasi $0 \mathrm{mg} / \mathrm{kg}$ BB signifikan $(\mathrm{P}<0,05)$ biji pepaya $50 \mathrm{mg} / \mathrm{kg} \mathrm{BB}$, daun mimba $50 \mathrm{mg} / \mathrm{kg}$ BB , campuran $50 \mathrm{mg} / \mathrm{kg} \mathrm{BB}$, biji pepaya $100 \mathrm{mg} / \mathrm{kg} \mathrm{BB}$ , daun mimba $100 \mathrm{mg} / \mathrm{kg} \mathrm{BB}$, campuran $100 \mathrm{mg} / \mathrm{kg}$ BB. pada biji pepaya $50 \mathrm{mg} / \mathrm{kg} \mathrm{BB}$ signifikan ( $\mathrm{P}<0,05$ ) kontrol $0 \mathrm{mg} / \mathrm{kg} \mathrm{BB}$, daun mimba $50 \mathrm{mg} / \mathrm{kg}$ $\mathrm{BB}$, campuran $50 \mathrm{mg} / \mathrm{kg} \mathrm{BB}$, biji pepaya $100 \mathrm{mg} / \mathrm{kg}$ $\mathrm{BB}$, daun mimba $100 \mathrm{mg} / \mathrm{kg} \mathrm{BB}$, campuran 100 $\mathrm{mg} / \mathrm{kg}$ BB. pada daun mimba $50 \mathrm{mg} / \mathrm{kg} \quad \mathrm{BB}$ signifikan $(\mathrm{P}<0,05)$ kontrol $0 \mathrm{mg} / \mathrm{kg} \mathrm{BB}$, biji pepaya $50 \mathrm{mg} / \mathrm{kg} \mathrm{BB}$, daun mimba $100 \mathrm{mg} / \mathrm{kg} \mathrm{BB}$, campuran $50 \mathrm{mg} / \mathrm{kg} \mathrm{BB}$, biji pepaya $100 \mathrm{mg} / \mathrm{kg} \mathrm{BB}$ , campuran $100 \mathrm{mg} / \mathrm{kg} \mathrm{BB}$.

Diameter tubulus seminiferus pada konsentrasi biji pepaya $100 \mathrm{mg} / \mathrm{kg}$ BB signifikan $(\mathrm{P}<0,05) \mathrm{kontrol} 0 \mathrm{mg} / \mathrm{kg} \mathrm{BB}$, biji pepaya $50 \mathrm{mg} / \mathrm{kg}$ $\mathrm{BB}$, daun mimba $50 \mathrm{mg} / \mathrm{kg} \mathrm{BB}$, campuran $50 \mathrm{mg} / \mathrm{kg}$ $\mathrm{BB}$, campuran $100 \mathrm{mg} / \mathrm{kg}$ BB. pada daun mimba $100 \mathrm{mg} / \mathrm{kg}$ BB signifikan ( $\mathrm{P}<0,05$ ) kontrol $0 \mathrm{mg} / \mathrm{kg}$ $\mathrm{BB}$ biji pepaya $50 \mathrm{mg} / \mathrm{kg} \mathrm{BB}$, daun mimba $50 \mathrm{mg} / \mathrm{kg}$ $\mathrm{BB}$ dan biji pepaya $100 \mathrm{mg} / \mathrm{kg} \mathrm{BB}$, campuran 50 $\mathrm{mg} / \mathrm{kg} \mathrm{BB}$, campuran $100 \mathrm{mg} / \mathrm{kg}$ BB signifikan (P > $0,05)$.
Diameter tubulus seminiferus mencit pada konsentrasi campuran biji pepaya dan daun mimba $50 \mathrm{mg} / \mathrm{kg}$ BB signifikan $(\mathrm{P}<0,05)$ kontrol $0 \mathrm{mg} / \mathrm{kg}$ $\mathrm{BB}$, biji pepaya $50 \mathrm{mg} / \mathrm{kg} \mathrm{BB}$, daun mimba 50 $\mathrm{mg} / \mathrm{kg} \mathrm{BB}$, biji pepaya $100 \mathrm{mg} / \mathrm{kg}$ BB dan berbeda nyata dengan mimba $100 \mathrm{mg} / \mathrm{kg} \mathrm{BB}$, campuran 100 $\mathrm{mg} / \mathrm{kg}$ BB signifikan $(\mathrm{P}>0,05)$. pada campuran biji pepaya dan daun mimba $100 \mathrm{mg} / \mathrm{kg}$ BB signifikan ( $\mathrm{P}<0,05$ ) kontrol $0 \mathrm{mg} / \mathrm{kg} \mathrm{BB}$, biji pepaya $50 \mathrm{mg} / \mathrm{kg}$ BB , biji pepaya $100 \mathrm{mg} / \mathrm{kg} \mathrm{BB}$, daun mimba 50 $\mathrm{mg} / \mathrm{kg}$ BB dan mimba $100 \mathrm{mg} / \mathrm{kg} \mathrm{BB}$, campuran 50 $\mathrm{mg} / \mathrm{kg} \mathrm{BB}$ signifikan $(\mathrm{P}>0,05)$.

Konsentrasi yang terbaik untuk menurunkan diameter tubulus seminiferus adalah mimba 100 $\mathrm{mg} / \mathrm{kg}$ BB. Tetapi antara perlakuan mimba 100 $\mathrm{mg} / \mathrm{kg}$ BB dan campuran biji pepaya dan daun mimba $100 \mathrm{mg} / \mathrm{kg}$ BB secara statistik tidak berbeda nyata.

\section{Sel leydig}

Pada hasil peneletian dan analisa pengaruh pemberian ekstrak biji pepaya (carica papaya L), ekstrak daun mimba (Azadirahcta indica A.Juss) dan campuran ekstrak biji pepaya ( carica papaya L), dan ekstrak daun mimba( Azadirahcta indica A.Juss ) terhadap penurunan sel leydig mencit disajikan dalam lampiran 3. Hasil penelitian menunjukan bahwa perlakuan ekstrak biji pepaya, ekstrak daun mimba dan campuran ekstrak biji pepaya da daun mimba berpengaruh signifikan $(\mathrm{P}<0,05)$ terhadap sel leydig mencit (Mus musculus). 


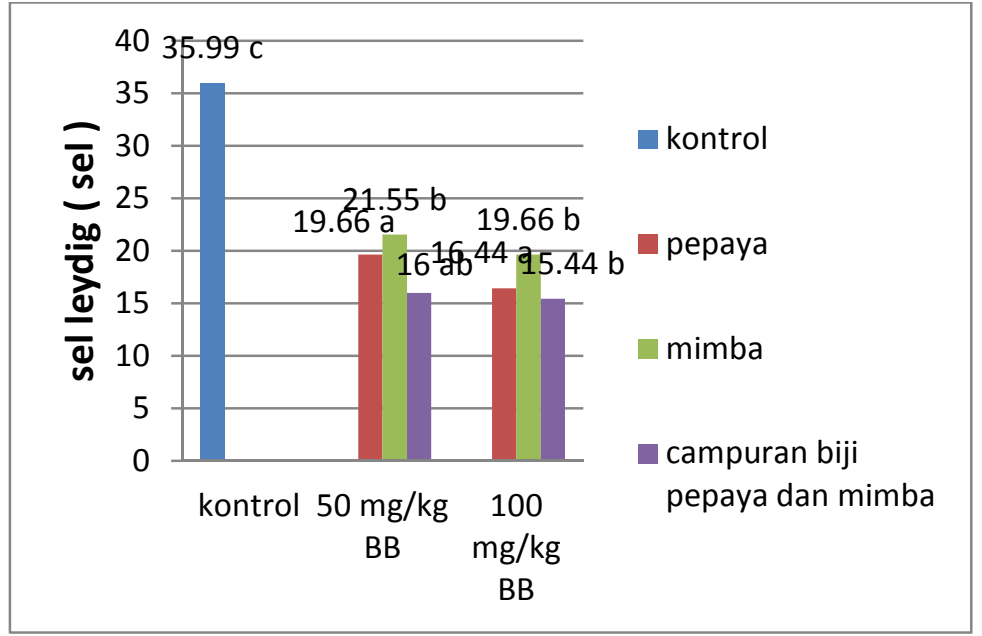

Sel leydig mencit (Mus musculus) yang diberi ekstrak biji pepaya dan daun mimba dan campuran dengan berbagai dosis. Hasil penelitian bahwa perlakuan dalam biji pepaya dan daun mimba juga campuran berpengaruh signifikan ( $\mathrm{P}<0,05)$ jumlah Sel leydig.

Sel leydig mencit pada Konsentrasi pada 0 $\mathrm{mg} / \mathrm{kg}$ BB signifikan $(\mathrm{P}<0,05)$ biji pepaya $50 \mathrm{mg} / \mathrm{kg}$ $\mathrm{BB}$, daun mimba $50 \mathrm{mg} / \mathrm{kg} \mathrm{BB}$, campuran $50 \mathrm{mg} / \mathrm{kg}$ $\mathrm{BB}$, biji pepaya $100 \mathrm{mg} / \mathrm{kg} \mathrm{BB}$, daun mimba 100 $\mathrm{mg} / \mathrm{kg} \mathrm{BB}$, campuran $100 \mathrm{mg} / \mathrm{kg}$ BB. pada biji pepaya $50 \mathrm{mg} / \mathrm{kg}$ BB signifikan $(\mathrm{P}<0,05)$ kontrol 0 $\mathrm{mg} / \mathrm{kg} \mathrm{BB}$, campuran $100 \mathrm{mg} / \mathrm{kg}$ BB. Dan daun mimba $50 \mathrm{mg} / \mathrm{kg} \mathrm{BB}$, campuran $50 \mathrm{mg} / \mathrm{kg} \mathrm{BB}$, biji pepaya $100 \mathrm{mg} / \mathrm{kg}$ BB , daun mimba $100 \mathrm{mg} / \mathrm{kg}$ BB $(\mathrm{P}>0,05)$. pada daun mimba $50 \mathrm{mg} / \mathrm{kg}$ BB signifikan $(\mathrm{P}<0,05)$ kontrol $0 \mathrm{mg} / \mathrm{kg} \mathrm{BB}$, biji pepaya $100 \mathrm{mg} / \mathrm{kg}$ $\mathrm{BB}$, campuran $50 \mathrm{mg} / \mathrm{kg} \mathrm{BB}$, campuran $100 \mathrm{mg} / \mathrm{kg}$ $\mathrm{BB}$ dan biji pepaya $50 \mathrm{mg} / \mathrm{kg} \mathrm{BB}$, daun mimba 100 $\mathrm{mg} / \mathrm{kg}$ BB $(\mathrm{P}>0,05)$.

Sel leydig mencit pada konsentrasi biji pepaya $100 \mathrm{mg} / \mathrm{kgBB}$ signifikan $(\mathrm{P}<0,05)$ kontrol $0 \mathrm{mg} / \mathrm{kg}$ $\mathrm{BB}$, daun mimba $50 \mathrm{mg} / \mathrm{kg}$ BB dan biji pepaya 50 $\mathrm{mg} / \mathrm{kg} \mathrm{BB}$, daun mimba $100 \mathrm{mg} / \mathrm{kg} \mathrm{BB}$, campuran $50 \mathrm{mg} / \mathrm{kg} \mathrm{BB}$, campuran $100 \mathrm{mg} / \mathrm{kg}$ BB $(\mathrm{P}>0,05)$. pada daun mimba $100 \mathrm{mg} / \mathrm{kg}$ BB signifikan $(\mathrm{P}<0,05)$ kontrol $0 \mathrm{mg} / \mathrm{kg} \mathrm{BB}$, campuran $100 \mathrm{mg} / \mathrm{kg}$ BB dan biji pepaya $50 \mathrm{mg} / \mathrm{kg} \mathrm{BB}$, daun mimba $50 \mathrm{mg} / \mathrm{kg} \mathrm{BB}$, campuran $50 \mathrm{mg} / \mathrm{kg} \mathrm{BB}$, biji pepaya $100 \mathrm{mg} / \mathrm{kg} \mathrm{BB}$ $(\mathrm{P}>0,05)$. pada campuran biji pepaya dan daun mimba $50 \mathrm{mg} / \mathrm{kg}$ BB signifikan $(\mathrm{P}<0,05)$ kontrol 0 $\mathrm{mg} / \mathrm{kg} \mathrm{BB}$, mimba $50 \mathrm{mg} / \mathrm{kg}$ BB dan biji pepaya 50 $\mathrm{mg} / \mathrm{kg} \mathrm{BB}$, daun mimba $100 \mathrm{mg} / \mathrm{kg} \mathrm{BB}$, biji pepaya $100 \mathrm{mg} / \mathrm{kg} \mathrm{BB}$, campuran $100 \mathrm{mg} / \mathrm{kg}$ BB (P> 0,05). pada campuran biji pepaya dan daun mimba 100 $\mathrm{mg} / \mathrm{kg}$ BB signifikan $(\mathrm{P}<0,05)$ kontrol $0 \mathrm{mg} / \mathrm{kg} \mathrm{BB}$, biji pepaya $50 \mathrm{mg} / \mathrm{kg} \mathrm{BB}$, daun mimba $50 \mathrm{mg} / \mathrm{kg} \mathrm{BB}$ , daun mimba $100 \mathrm{mg} / \mathrm{kg}$ BB dan campuran 50 $\mathrm{mg} / \mathrm{kg} \mathrm{BB}$, biji pepaya $100 \mathrm{mg} / \mathrm{kg}$ BB karena nilai signifikansi $(\mathrm{P}>0,05)$.

Konsentrasi yang terbaik untuk menurunkan jumlah sel leydig adalah ekstrak campuran biji pepaya dan daun mimba $100 \mathrm{mg} / \mathrm{kg}$ BB. Tetapi antara perlakuan campuran biji pepaya dan daun mimba $100 \mathrm{mg} / \mathrm{kg}$ BB dan campuran biji pepaya dan daun mimba $50 \mathrm{mg} / \mathrm{kg}$ BB secara statistik tidak berbeda nyata.

\section{Pembahasan}

Hasil penelitian ini mengindenfisikan bahwa perlakuan dalam biji pepaya dan daun mimba dan campuran biji pepaya dan daun mimba beda secara alami maupun campuran dapat menurunkan diameter tubulus seminiferus, sel leydig, dan berat testis mencit.

Kandungan senyawa pada daun mimba adalah flavonoid dan kandungan pada biji pepaya adalah alkaloid. Menurut Kellis dan Vickery (1984) flavanoid yang disintesis oleh hampir seluruh dunia tumbuhan dapat menghambat enzim aromatase. Enzim aromatase berfungsi sebagai katalis untuk mengonversi androgen menjadi estrogen. Dengan dihambatnya enzim tersebut maka jumlah androgen (testosteron) akan meningkat. Tingginya konsentrasi testosteron akan menghasilkan kerusakan pada sel sertoli dan tubulus seminiferus (Kholkute, 2007). LH dan FSH dari hipofisa anterior memegang peranan penting dalam mengatur proses biologi reproduksi pada hewan jantan, FSH merangsang proses spermatogenesis dan LH yang sering disebut ICSH (Interstitial Cell Stimulating Hormone), merangsang pertumbuhan dan metabolisme sel-sel leydig, untuk memproduksi hormon testosteron. Jumlah sperma dan kadar testosteron dipertahankan konstan oleh mekanisme umpan balik. Jika mekanisme umpan balik negatif terganggu maka kadar FSH dan LH dalam peredaran darah menurun, akibatnya proses spermatogenesis terhenti dan jumlah spermatozoa yang dihasilkan menurun. (Melo, 2010) menyatakan testis berukuran normal memiliki hubungan positif dengan potensi substansi fungsional (tubulus seminiferus) yang terkandung dalam testis.

Saponin dan alkaloid digunakan sebagai bahan baku sintesis hormon steroid dan triterpenoid 
memiliki kaitan dengan biogenesis dengan steroid (Robinson, 1991). Diduga saponin ikut masuk ke dalam jalur biosintesa steroid terutama hormon estrogen sehingga akan dihasilkan bahan yang strukturnya mirip dengan hormon tersebut. Selanjutnya bahan ini disekresi bersama dengan hormon tersebut bersama sel terget. Pada sel target bahan tersebut akan masuk ke sel bersama dengan hormon, selanjutnya akan menempati reseptor hormon. Akibatnya aksi hormon pada sel target akan berkurang. Menurut Turner dan Bagnara (1976) dikatatakan bahwa bahan anti estrogen bekerja secara kompetitif pada lokasi reseptor jaringan sasaran untuk menghalangi aksi steroid estrogen. Saponin digunakan sebagai bahan baku untuk sintesis hormon steroid, dan digunakan sebagai estrogen kontraseptif. Alkaloid, terutama alkaloid steroid sangat mirip dengan saponin yang digunakan sebgai bahan dasar sintesis beberapa hormon steroid untuk bahan kontrasepsi oral (Robinson, 1991).

Perubahan histopatologi dalam testis dapat dijadikan dasar dari perubahan histologi fungsi spermatogenesis terutama dalam tubulus seminiferus. Fungsi testis adalah produksi spermatozoa yang dihasilkan oleh bagian tubulus seminiferus dari testis. Berat dan ukuran testis dapat digunakan sebagai indikator kuantitatif produksi spermatozoa. Pengukuran diameter tubulus seminiferus merupakan penentu utama dari berat testis (Munson et., al., 1996) dan juga dapat digunakan untuk memprediksi produksi sperma (Krisnalingham, 1982).

Penelitian yang dilakukan oleh Muslichah dan Wiratmo (2013) tentang efek antifertilitas dari biji pepaya (Carica Papaya L.) terhadap tikus jantan galur wistar diperoleh hasil bahwa fraksi П-heksana, fraksi kloroform dan fraksi metanol biji pepaya dosis $100 \mathrm{mg} / \mathrm{kg}$ BB mampu menurunkan jumlah spermatozoa, motilitas, meningkatkan abnormalitas spermatozoa dan menurunkan viabilitas spermatozoa.

Pada penelitian ini pengamatan histopatologi testis menunjukkan bahwa nilai rata-rata berat, sel leydig, dan diameter tubulus seminiferus mencit (Mus musculus) pada kelompok perlakuan lebih kecil dibanding dengan kelompok kontrol. Hal ini menunjukkan adanya pengaruh yang bermakna dari pemberian ekstrak daun mimba (Azadirachta indica A.Juss) Berkurangnya ukuran diameter tubulus seminiferus mencerminkan adanya hambatan spermatogenesis (Kovacevic et., al., 2006) dan juga kemungkinan disebabkan banyaknya sel leydig yang mengalami apoptosis. Dalam epitel seminiferus, apoptosis dapat terjadi secara spontan atau sebagai respon terhadap beberapa faktor seperti agen kemoterapi, suhu tinggi dan hormonal (Costa and Silva, 2006). Testis dibagi oleh septa-septa jaringan ikat menjadi 200 - 300 buah lobuli. Masing-masing lobulus berisi satu sampai empat buah tubulus seminiferus (Gupta, 2005; Sherwood, 2001).
Hampir 80\% massa testis terdiri dari sel-sel spermatogenik di dalam tubulus seminiferus, sedangkan $20 \%$ sisanya terdiri dari jaringan ikat, pembuluh darah dan sel-sel yang ada diantaranya. Dari haasil penelitian diperoleh hasil bahwa bagian daun mimba.

Penelitian yang dilakukan oleh Suryawansih (2011) pada daun mimba terhadap tikus jantan yang dikawinkan dengan tikus betina, diperoleh hasil pada dosis $200 \mathrm{mg} / \mathrm{kg} \mathrm{BB}$ semua sperma non motil atau mati. Sedangkan pada dosis $150 \mathrm{mg} / \mathrm{kg}$ BB 3-4\% sperma berjalan lambat sedangkan sisanya yang lain non motil atau mati. Penelitian yang dilakukan oleh Muslichah dan Wiratmo (2014) tentang kombinasi dari biji saga (Abrus precatorius L.) dan biji pepaya (Carica papaya L.) terhadap tikus putih galur wistar, menunjukan bahwa dosis paling optimal yang disarankan adalah perbandingan 50:50 mg/kg BB, ini terkait dengan resiko efek toksik yang mungkin bisa ditimbulkan. Jika dosis yang lebih rendah bisa menimbulkan efek antifertilitas yang sama dengan dosis diatasnya maka lebih baik digunakan dosis yang paling rendah. yang efektif menurunkan bobot testis dan diameter tubulus seminiferus adalah mimba pada dosis $100 \mathrm{mg} / \mathrm{kg}$ BB dan yang menurunkan sel leydig adalah campuran biji pepaya dan mimba pada dosis $100 \mathrm{mg} / \mathrm{kg}$ BB Diduga kandungan senyawa flavanoid, dan tanin yang terdapat pada mimba lebih tinggi dari pada bagian pepaya dan campuran pepaya dan mimba .sebagai tambahan penelitian terdahulu

\section{KESIMPULAN}

Penelitian dapat disimpulkan Terdapat pengaruh ekstrak ekstrak biji pepaya (carica papaya L.) dan ekstrak daun mimba (Azadirachta india A.Juss ) dan campuran biji pepaya dan daun mimba terhadap penurunan diameter tubulus seminiferus, sel leydig, dan berat testis mencit (Mus musculus). Bagian ekstrak daun mimba (Azadirachta india A.Juss, yang menurunkan berat testis, dan diameter tubulus seminiferus terbaik adalah mimba dengan dosis $100 \mathrm{mg} / \mathrm{kg}$ BB dan Bagian ekstrak campuran biji pepaya (carica papaya L.) dan ekstrak daun mimba (Azadirachta india A.Juss) yang menurunkan sel leydig terbaik adalah campuran dengan dosis $100 \mathrm{mg} / \mathrm{kg} \mathrm{BB}$.

\section{DAFTAR PUSTAKA}

Adnan, 2002. Potensi Tumbuhan Sebagai Bahan Pengatur Fertilitas. Makasar : Biologi, FMIPA, Universitas Muhammadiyah Makasar

Basha and Cangamma, 2003. Effect of Carica papaya $L$. seed on Lipid Metabolity in Male Albino Rats, int J Pharm set 5 (4)

Behre, 2003. Reproductive and Fertility Effect of An Extract of Andrographis Paniculata In Male Wistar Rats. Internationnal Journal of Toxicology, 28 (4) : $308-317$ 
Burrow M.E, S.M. Bone, B.M. Coelin, L.I Meinik, B.N Duana, S.W. Canter, T.E.Wiese, T.E Cleveland and J.A. Mc. Lachlan, 2001. Phytochemical Gliceolins Isolated from Soy Medicine Antihormonal Effect Through Estrogen Receptor Alpha and Beta. J. Clin. Endocrinol. Metab. Apr. 86 (4) : 1750-1758

Campbell, Reece, Mitchell, 2004. Biologi. Jakarta : Erlangga

Christiajanti Wulan, 2007. Efek Antifertilitas Ekstrak Daun Sambiloto Pada Kualitas Spermatozoa Mencit Jurnal Kedokteran Media Indonesia. FK UNDIP Vol. 42 N0. 2

Csruhes S, 2008. Pest Plant Risk Assessment Neem Tree (Azadirachta indica juss), Queenslan, Australia : Departement of Primary Industries and Fisheries

Depkes, 2006. 18 Jenis Tanaman Obat Turunkan Kesuburan Pria. www.depkes.go.id. Diunduh 28 November 2015

Francis G., Z. Kerem, H.P.S. Makkar and K. Becker, 2002. The Biological Action of Saponins in Animal System : Review. British Journal of Nutrition 88:587-605

Fitriyah, 2005. Pengaruh Ekstrak Buah Pinang (Area catechu) Terhadap Hsitologi Testis Mencit (Mus musculus). Bandung : Pendidikan Bahasa Indonesia, FKIP, Univerista Pendidikan Indonesia
Ganang M. D, William, 2003. Fisiologi Manusia dan Mekanisme Penyakit. Terjemahan Pertus Andrianto. Jakarta : EGC Penerbit Buku Kedokteran pada Tikus Putih (Rattus norvegicus) Jantan. Pusat Studi Katahanan Pangan. Lembaga Penelitian dan Pengabdian Kepada Masyarakat. Universitas Udayana

Gofur, 2002. Rebung Bambu Tabah (Gigantochloa nigrociliata) Sebagai Bahan Afrodisiak

Guyton, Artur C, 2005. Fisiologi Manusia dan Mekanisme Penyakit, Penerjemah Petrus Andrianto. Jakarta : EGC

Handayani S.M, Djatmiko M., Anas Y., 2011. Uji Aktifitas Rappelent Frakni N-Heksana Ekstrak Etanolik Daun Mimba (Azadirachta indica A Juss) Terhadap Nyamuk Aedes aegypti. Sumatera : Biologi, FMIPA, Universitas Sumatera Utara

Handayani. 2001. Pengaruh Ekstrak Daun Suren dan Daun Mahoni terhadap Mortalitas dan Aktivitas Makan Ulat Daun (Plutella xylostella) pada Tanaman Kubis. LenteraBio Vol. 2 No. 1 Januari 2001: 95-99

Hariadi, 2012. Peluang Jitu Beternak Tikus Putih. Yogyakarta : Pustaka Baru Press

Hasanah Ifnaini Wirdatul, 2009. Pengaruh Ekstrak Daun Pegagan (Centella asiatica) Terhadap Spermatogenesis Mencit (Mus muscullus). Malang. 